TITLE:

\title{
A New Form of the Bivalve- Inhabiting Hydrozoan Eutima japonica (Leptomedusae, Eirenidae) in Japan
}

AUTHOR(S):

Kubota, Shin

CITATION:

Kubota, Shin. A New Form of the Bivalve-Inhabiting Hydrozoan Eutima japonica

(Leptomedusae, Eirenidae) in Japan. PUBLICATIONS OF THE SETO MARINE BIOLOGICAL LABORATORY 1997, 38(1-2): 73-81

ISSUE DATE:

1997-12-25

URL:

http://hdl.handle.net/2433/176269

RIGHT: 


\title{
A New Form of the Bivalve-Inhabiting Hydrozoan Eutima japonica (Leptomedusae, Eirenidae) in Japan
}

\author{
Shin Kubota \\ Seto Marine Biological Laboratory, Kyoto University, \\ Shirahama, Nishimuro, Wakayama 649-2211, Japan
}

\begin{abstract}
Further intraspecific variability of Eutima japonica is described and illustrated. The newly matured medusa of this so-called "transitional" form, the hydroid of which is associated with the bivalve Barbatia virescens from Kôshima Island off Kyushu, southern Japan ( $53.8 \%$ prevalence), is more developed than the medusa of the intermedia form, but is less developed than the medusae of the southern and northern forms. The major morphological features of the new form's newly matured, 7- to 14-day-old medusae of both sexes are: a very short peduncle of only $0.3-1.5 \mathrm{~mm}$ in length, four $(61.7 \%$ of individuals $)$ or eight $(34.0 \%)$ tentacles, a medium-sized umbrellar diameter $(4.8-7.4 \mathrm{~mm})$, and a large but variable number (0-67) of lateral cirri. The life-span of the medusae in the laboratory at $22 \pm 1^{\circ} \mathrm{C}$ was relatively short, about one month.
\end{abstract}

Key words: intraspecific variability, transitional form, Hydrozoa, Eutima japonica, Barbatia virescens, Japan, medusa, life-span

\section{Introduction}

In Japanese waters the bivalve-inhabiting hydrozoan Eutima japonica Uchida, 1925 comprises three forms, the northern, the southern, and the intermedia forms. The morphology of their medusae is different, particularly in the newly matured medusae (Kubota, 1983, 1984, 1985a, b, 1990, 1992a, 1993).

Recently Eutima japonica was collected on two occasions from a new locality in southern Japan. Many immature medusae, which were released from the hydroids in the laboratory within two months after collection, were reared for about one month in order to determine the form. This turned out to be a new, fourth form of E. japonica, which is described and illustrated in detail in this paper, together with an estimate of the life-span of the medusa. Moreover, a morphological comparison is made between the present form and the type specimens.

\section{Material and methods}

The host bivalve, Barbatia virescens (Reeve) attached to intertidal rocks at Kôshima Island, Miyazaki Prefecture, Kyushu, southern Japan, was collected on May 27 and November 21, 1994. Medusa buds had already formed on both these occasions. The host bivalves harbouring hydroids and the released medusae were reared singly in the laboratory in 80 or $60 \mathrm{ml}$ polystyrene vessels filled with filtered seawater from Shirahama, Wakayama Prefecture at $22 \pm 1{ }^{\circ} \mathrm{C}$ under alternating $12 \mathrm{~h}$ periods of light and dark, and they were fed daily with newly hatched Artemia nauplii. The seawater was changed every day. The growth of the medusae was observed every day at least until the maturation of the gonads. Measurements were made from medusae relaxed in a $10 \% \mathrm{MgCl}_{2}$ solution. The following description is based mainly on the specimens reared at $22 \pm 1^{\circ} \mathrm{C}$. The morphology of early- and late-stage medusae grown at $15 \pm 1{ }^{\circ} \mathrm{C}$ under near-natural light conditions is also described for comparison. 


\section{Description of the transitional form of Eutima japonica}

The newly matured medusa

\section{Description}

Between the 7 th and 14th day after liberation all the medusae matured and had oblong gonads with a variable length; females spawned many unfertilized eggs and the gonads of males became milky white in colour. A very small number of medusae were reared from each host, and in one host both sexes appeared. The umbrellas were $4.8-7.4 \mathrm{~mm}$ in diameter. The medusae of both sexes always had a short peduncle $0.3-1.5 \mathrm{~mm}$ in length; four $(61.7 \%$ of the individuals) or eight $(34.0 \%)$ tentacles; many lateral cirri $(20-39$ in $53.6 \%$ of the individuals and up to 67 , except for two females without cirri); 16-45 marginal warts; and eight statocysts (rarely nine) (Figs. 1, 2; Tables 1, 2). All the specimens of both sexes less than $6.0 \mathrm{~mm}$ in diameter had four tentacles. In one specimen of each sex the four interradial tentacles were shorter than the four perradial tentacles. The number of lateral cirri per specimen is more variable in females than males. All the cirri disappeared in two female medusae originating from the same host (only these two medusae were reared from this host) (Fig. 2). Most of the statocysts contained 5-7 statoliths (Table 3). One extraordinarily small statocyst contained three statoliths. The oral lips were folded once and the manubrium was wholly within the subumbrellar cavity, not reaching the umbrellar aperture (Fig. 1).

Remarks

The newly matured medusa of the present form is usually more precocious than that of the northern and southern forms, which are not commensal with the present host species, but maturation is not as precocious as that of the so-called intermedia form,

Table 1. Age and morphology of newly matured medusae of the transitional form of Eutima japonica. Measurements include range, mean $\pm \mathrm{SD}$, and number examined.

\begin{tabular}{|c|c|c|}
\hline & Males & Females \\
\hline Ages of medusae (days) & $7-14,10 \pm 2, N=29$ & $8-13,11 \pm 1, N=18$ \\
\hline $\begin{array}{l}\text { No. of hosts from which } \\
\text { medusae released }\end{array}$ & 15 & 11 \\
\hline Umbrellar diameter (mm) & $4.8-7.0,5.9 \pm 0.6, N=29$ & $5.8-7.4,6.5 \pm 0.5, \mathrm{~N}=18$ \\
\hline Umbrellar height (mm) & $3.3-4.6,3.8 \pm 0.4, \mathrm{~N}=14$ & $4.0-5.0,4.4 \pm 0.3, N=16$ \\
\hline $\begin{array}{l}\text { Thickness of mesogloea } \\
\text { at umbrellar apex ( } \mathrm{mm})\end{array}$ & $1.7-2.5,2.0 \pm 0.2, \mathrm{~N}=14$ & $1.7-3.0,2.2 \pm 0.3, \mathrm{~N}=16$ \\
\hline Length of peduncle $(\mathrm{mm})$ & $0.3-1.5,0.8 \pm 0.3, \mathrm{~N}=14$ & $0.3-1.5,1.0 \pm 0.3, \mathrm{~N}=16$ \\
\hline Length of manubrium ( $\mathrm{mm}$ ) & $1.2-1.4,1.2 \pm 0.1, \mathrm{~N}=14$ & $1.3-1.6,1.5 \pm 0.1, \mathrm{~N}=16$ \\
\hline Total no. of tentacles & $4-8,5 \pm 2, \bar{N}=29$ & $4-8,6 \pm 2, N=18$ \\
\hline Total no. of marginal warts & $16-45,26 \pm 6, \mathrm{~N}=29$ & $17-32,23 \pm 6, \mathrm{~N}=18$ \\
\hline $\begin{array}{l}\text { Max. no. of marginal warts } \\
\text { in a quadrant/medusa }\end{array}$ & $3-10,7 \pm 1, N=29$ & $2-8,6 \pm 2, N=18$ \\
\hline Total no. of lateral cirri & $16-60,31 \pm 12, N=14$ & $0-67,23 \pm 20, N=15$ \\
\hline $\begin{array}{l}\text { Max. no. of lateral cirri on a } \\
\text { marginal swelling/medusa }\end{array}$ & $2-5,3 \pm 1, N=15$ & $0-5,3 \pm 2, N=15$ \\
\hline Total no. of statocysts & $8,8 \pm 0, N=24$ & $8-9,8 \pm 0, N=17$ \\
\hline Total no. of statoliths & $39-57,45 \pm 7, \mathrm{~N}=15$ & $36-59,51 \pm 6, N=15$ \\
\hline No. of statoliths/statocyst & $1-9,6 \pm 1, N=120$ & $3-9,6 \pm 1, N=121$ \\
\hline
\end{tabular}




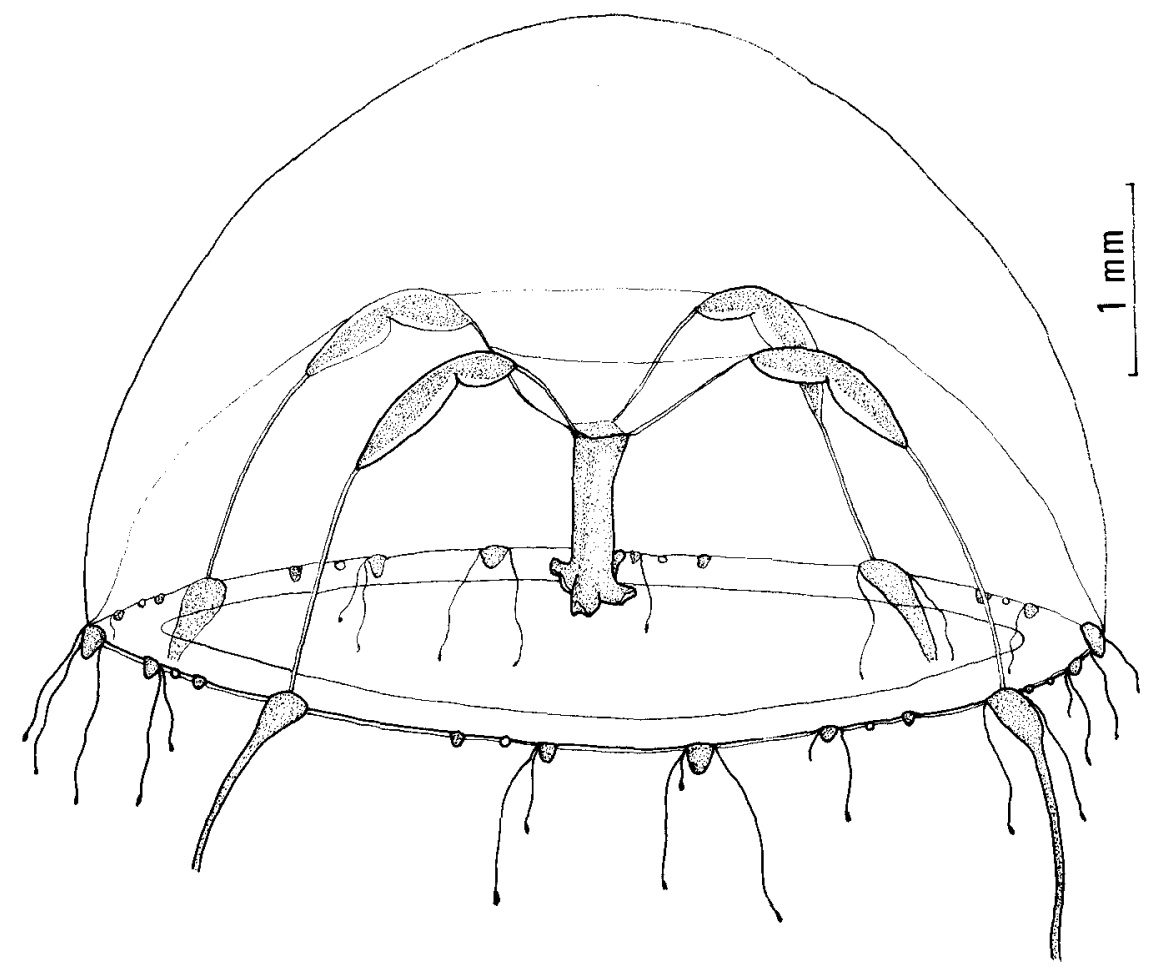

Fig. 1. Newly matured male medusa of the transitional form of Eutima japonica. An 8-day-old medusa reared in the laboratory at $22 \pm 1{ }^{\circ} \mathrm{C}$. Only proximal parts of the marginal tentacles are drawn.

Table 2. Frequency distribution of number of tentacles of newly matured medusae of the transitional form of Eutima japonica.

\begin{tabular}{lrrrrr}
\hline No. of tentacles & 4 & 5 & 6 & 7 & 8 \\
\hline Males & 22 & 0 & 1 & 0 & 6 \\
Females & 7 & 0 & 0 & 1 & 10 \\
\hline
\end{tabular}

Table 3. Frequency distribution of number of statoliths per statocyst in newly matured medusae of the transitional form of Eutima japonica.

\begin{tabular}{llllllllllll}
\hline $\begin{array}{l}\text { Number of stato- } \\
\text { liths/statocyst }\end{array}$ & 1 & 2 & 3 & 4 & 5 & 6 & 7 & 8 & 9 \\
\hline $\begin{array}{l}\text { Males } \\
\text { Females }\end{array}$ & 1 & 0 & 4 & 12 & 34 & 41 & 24 & 3 & 1 \\
\hline total & 0 & 0 & 1 & 4 & 19 & 43 & 39 & 12 & 2 \\
\hline
\end{tabular}

which is commensal with the present host species (Table 4). Except for the complete absence of the lateral cirri in the northern form and two specimens of the present material, the morphology of the newly matured medusae of Eutima japonica in Japan becomes more 


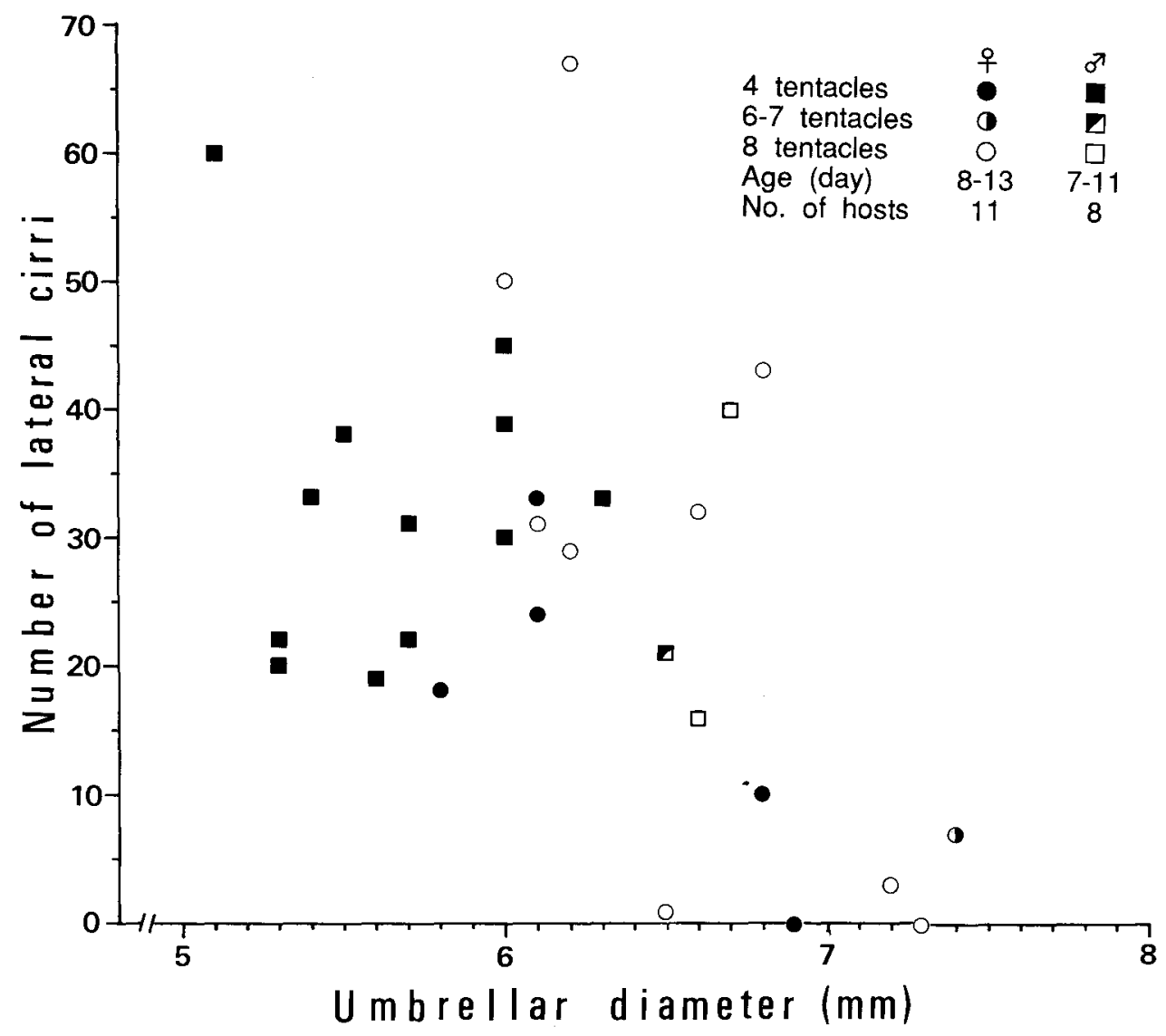

Fig. 2. Variation of number of the tentacles and the lateral cirri in newly matured medusae of the transitional form of Eutima japonica (7-13 days old).

Table 4. Morphological comparison of newly matured medusae of known forms of Eutima japonica, including present new transitional form.

\begin{tabular}{|c|c|c|c|c|c|c|c|}
\hline Form & $\begin{array}{l}\text { Length of } \\
\text { peduncle } \\
(\mathrm{mm})\end{array}$ & $\begin{array}{l}\text { No. of } \\
\text { tentacles* }\end{array}$ & $\begin{array}{l}\text { Presence } \\
\text { of lateral } \\
\text { cirri* }\end{array}$ & $\begin{array}{l}\text { Umbrellar } \\
\text { diameter } \\
(\mathrm{mm})\end{array}$ & $\begin{array}{l}\text { Age } \\
\text { (days) }\end{array}$ & $\begin{array}{l}\text { Water } \\
\text { temperature } \\
\text { reared }\left({ }^{\circ} \mathrm{C}\right)\end{array}$ & References \\
\hline intermedia & 0 & 4 & many & $1.5-3.4$ & $3-13$ & $18-23$ & Kubota, 1984, 1985a \\
\hline transitional & $0.3-1.5$ & 4 or 8 & many & $4.8-7.4$ & $7-14$ & $21-23$ & present study \\
\hline northern & $0.5-2.4$ & 8 & none & $5.4-11.1$ & $9-33$ & $18-24$ & $\begin{array}{c}\text { Kubota, } 1978,1979 \\
1983,1985 b\end{array}$ \\
\hline southern & $1.6-4.8$ & 8 & many & $9.4-12.2$ & $24-35$ & $19-21$ & Kubota, 1983, 1990 \\
\hline
\end{tabular}

* rare cases are not included.

complex from form to form in the order, intermedia-transitional-northern-southern, correlating with an increase in size and a successively longer period required for the maturation of the gonads (Table 4). 
The type specimens, two mature medusae, were described by Uchida (1925); one from Misaki (Kanagawa Pref.) and the other from Yunohama (Yamagata Pref.) were collected in 1922 before the introduction of Mytilus edulis galloprovincialis into Japan from Europe. The hosts of these types are unknown. There are some morphological inconsistencies between the present form and the type specimens. In some respects, the present form is slightly more developed morphologically than the types: the umbrella is larger (4.8-7.4 mm wide vs $4.5 \mathrm{~mm}$ wide, and $3.3-5.0 \mathrm{~mm}$ high vs $3.0 \mathrm{~mm}$ high); the statocysts contains more statoliths (3-9 but usually $5-7$ vs 3 ). On the other hand, the present form is slightly less developed in other features: the number of tentacles is often smaller (4 vs 8 ); the gonads are sometimes shorter.

The life-span of the medusa

In both sexes the life-span of the medusae is about one month on average (Table 5). This life-span is shorter than those of the northern and southern forms (see Kubota, 1983), but similar to that of the intermedia form (see Kubota, 1985a).

At $15 \pm 1{ }^{\circ} \mathrm{C}$ the medusae survived longer than those reared at $22 \pm 1{ }^{\circ} \mathrm{C}$. This is due to slower growth at low temperature, as is shown below (see Tables 7, 8; Fig. 3).

Morphology of some developmental stages of the medusa

(1) Newly released medusae

The present medusae usually have two perradial tentacles $(80.5 \%$ of the individuals, see Table 6), as in the southern and intermedia forms. Four tentacles at liberation, a feature of the northern form (see Kubota, 1985b), was found in $11.0 \%$ of the individuals (Table 6). Unlike some of the intermedia form, no trace of gonads was observed along the proximal portions of the radial canals in this youngest stage (see Kubota, 1985a). Therefore, the morphology of medusae of this stage resembles that of the southern form.

Table 5. Frequency distribution, range, and mean \pm SD of life-spans of medusae of the transitional form of Eutima japonica reared at $22^{\circ} \mathrm{C}$.

\begin{tabular}{lcclcc}
\hline Life-span & $15-29$ days* & $30-44$ days* & Range & Mean \pm SD & $N$ \\
\hline Males & 6 & 10 & $18-40$ days & $29 \pm 6$ days & 16 \\
Females & 12 & 7 & $18-35$ days & $27 \pm 5$ days & 19 \\
\hline Total & 18 & 17 & $18-40$ days & $28 \pm 5$ days & 35 \\
\hline
\end{tabular}

* The life-span is divided into intervals of 15 days because a 14-day-old individual was the oldest newly matured medusa.

Table 6. Frequency distribution of number of tentacies of 1-day-old medusae of the transitional form of Eutima japonica reared from hydroids associated with 23 specimens of Barbatia virescens.

\begin{tabular}{llcccc}
\hline Number of tentacles & 1 & 2 & 3 & 4 \\
\hline Number of individuals & 1 & 66 & 6 & 9 \\
\hline
\end{tabular}


(2) Four-tentacle stage, excluding newly released medusae with four tentacles

Medusae reared at $22 \pm 1^{\circ} \mathrm{C}$ attained the 4-tentacle stage earlier than those reared at $15 \pm 1^{\circ} \mathrm{C}$ and their umbrella tended to be smaller (Fig. 3). At $22 \pm 1^{\circ} \mathrm{C}$, for example, the youngest medusae with two tentacles attained this stage by the third day, when the umbrella was $1.6-1.8 \mathrm{~mm}$ in diameter $(\mathrm{N}=3)$. However, at $15 \pm 1^{\circ} \mathrm{C}$ this did not happen until the 7-10th day, when the umbrellar diameter was larger, 2.3-3.0 $\mathrm{mm}(\mathrm{N}=2)$ (Fig. 3). All the specimens at this stage showed no trace of gonads, and they all had four interradial marginal warts except for the largest specimen, which in addition had two marginal warts

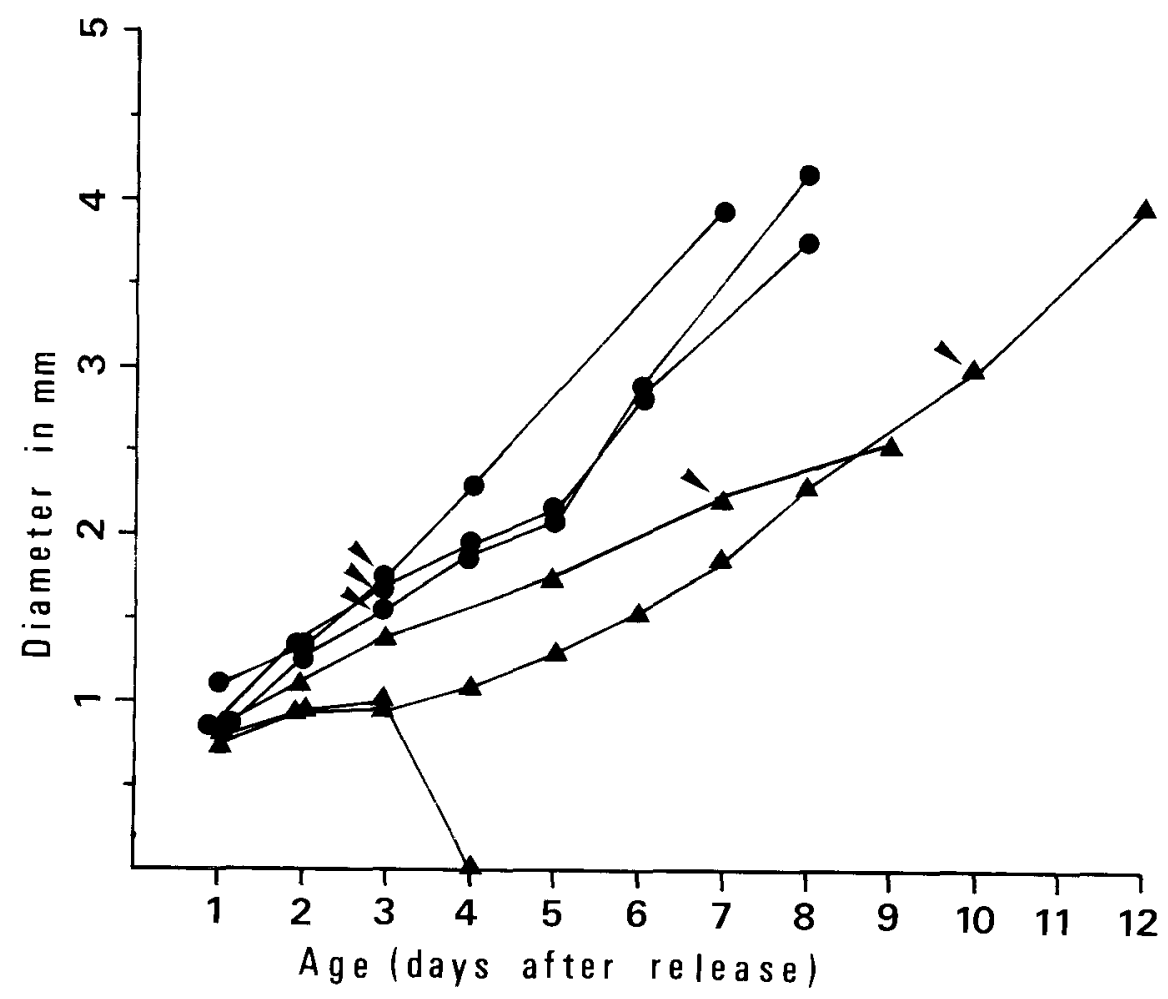

Fig. 3. Umbrella sizes of medusae of the transitional form of Eutima japonica in early developmental stages reared at $22 \pm 1^{\circ} \mathrm{C}$ (circles) and $15 \pm 1^{\circ} \mathrm{C}$ (triangles). A delay is noted in attaining the 4-tentacle stage (arrows) at the lower temperature.

Table 7. Age and morphology of medusae with newly formed peduncle in the transitional form of Eutima japonica reared at two different water temperatures. Measurements include range, mean $\pm \mathrm{SD}$, and number examined.

\begin{tabular}{lll}
\hline & $22^{\circ} \mathrm{C}$ & $15^{\circ} \mathrm{C}$ \\
\hline Age (days) & $4-9,7 \pm 1, \mathrm{~N}=51$ & $11,11 \pm 0, \mathrm{~N}=9$ \\
Umbrellar diameter $(\mathrm{mm})$ & $3.2-5.5,4.4 \pm 0.5, \mathrm{~N}=51$ & $4.1-5.7,5.0 \pm 0.5, \mathrm{~N}=9$ \\
Number of tentacles & $4,4 \pm 0, \mathrm{~N}=51$ & $4,4 \pm 0, \mathrm{~N}=9$ \\
Number of marginal warts & $14-22,18 \pm 2, \mathrm{~N}=37$ & no data \\
Number of hosts examined & 19 & 6 \\
\hline
\end{tabular}


in adradii.

(3) Medusae with newly produced peduncle

The peduncle was always produced after the medusae had developed four tentacles. Small, immature gonads appeared at this stage. The umbrella was $3.2-5.5 \mathrm{~mm}$ in diameter, larger than that of the 4-tentacle stage reared at $15 \pm 1{ }^{\circ} \mathrm{C}$, but smaller than in all newly matured female medusae, and overlapping some newly matured male medusae (see Tables 1, 7). Medusae reared at $15 \pm 1^{\circ} \mathrm{C}$ attained this stage later than those reared at $22 \pm 1^{\circ} \mathrm{C}$, and they showed a similar morphology, although their umbrella tended to be larger (Table 7).

(4) Old medusae

Rearing of five newly matured male medusae with four tentacles and many cirri (originating from four host specimens) and one newly matured male medusa with eight tentacles and many cirri (originated from another host specimen) was continued for several weeks. Eventually all these medusae at 21-28 days old had eight tentacles owing to the formation of the four interradial tentacles. All these specimens had many cirri, and their peduncles reached the umbrellar aperture as a result of elongation. The umbrella grew to $7.7-8.2 \mathrm{~mm}$ in diameter and the marginal warts increased in number (24-45). Such features in the present old medusae coincide with those in the medusae of the southern form and extraordinary specimens of the intermedia form (Kubota, 1983, 1990, 1993).

The morphology of 41- to 56-day-old medusae reared at $15 \pm 1{ }^{\circ} \mathrm{C}$, which had umbrellar diameters of $8.0-9.3 \mathrm{~mm}$ and 16-45 marginal warts (Table 8), was similar to that of the above-mentioned 21 to 28 -day-old medusae reared at $22 \pm 1^{\circ} \mathrm{C}$, though with fewer (6-15) lateral cirri in most of the specimens.

Table 8. Morphology of old medusae of the transitional form of Eutima japonica reared at $15^{\circ} \mathrm{G}$.

\begin{tabular}{lccc}
\hline & Males & Females & ?Females \\
\hline No. of medusae examined & 2 & 3 & 2 \\
No. of hosts from which medusae released & 2 & 3 & 1 \\
Ages of medusae (days) & 47,56 & $55,55,56$ & 41,55 \\
Umbrellar diametcr (mm) & $8.3,8.0$ & $8.6,9.0,8.2$ & $8.3,9.3$ \\
Umbrellar height (mm) & $6.5,7.5$ & $7.1,7.0,6.5$ & $5.5,7.0$ \\
Thickness of mesogloea at umbrellar apex (mm) & $4.0,3.5$ & $4.0,4.0,4.0$ & $3.3,3.5$ \\
Length of peduncle (mm) & $2.5,3.0$ & $2.5,2.5,2.0$ & $3.3,4.0$ \\
Length of manubrium (mm) & $1.5,2.3$ & $1.5,2.0,1.5$ & $1.3,1.3$ \\
Total no. of tentacles & 8,8 & $8,8,8$ & 5,7 \\
Total no. of marginal warts & 19,19 & $16,45,24$ & 29,40 \\
Max. no. of marginal warts in a quadrant/medusa & 6,6 & $6,13,8$ & 8,11 \\
Total no. of lateral cirri & 6,11 & $15,34,15$ & 10,10 \\
Max. no. of lateral cirri on a marginal swelling/medusa & 2,2 & $1,2,2$ & 2,2 \\
Total no. of statocysts & 8,8 & $8,8,8$ & 10,8 \\
Total no. of statoliths & 82,61 & $82,93,80$ & 77,81 \\
No. of statoliths/statocyst & $8-12,6-9$ & $8-13,9-14,9-11$ & $4-11,9-11$ \\
\hline
\end{tabular}


Host

On May 27, 1994, six bivalve species of four genera were examined for hydroids at Kôshima Island (Table 9). Among these, Barbatia lima (Reeve) and Mytilus edulis galloprovincialis Lamarck were very rare, while Barbatia virescens (Reeve) and Hormomia mutabilis (Gould) were abundant. The hydroids were found only in B. virescens on this occasion. On a later occasion (Nov. 21, 1994) the present hydroid species was also commensal with $B$. virescens. Therefore, $B$. virescens is now a known host of the present new form and also of the intermedia form, but not of the northern and the southern forms (see Kubota, 1992b).

Table 9. Host preference of the transitional form of Eutima japonica.

\begin{tabular}{lcc}
\hline Bivalve species & $\begin{array}{l}\text { Association rate }(\%), \\
\text { no. of bivalve specimens } \\
\text { examined }\end{array}$ & $\begin{array}{l}\text { Size of bivalves (mm): } \\
\text { as shell length (L) or } \\
\text { anterior-posterior axis (APA) }\end{array}$ \\
\hline Barbatia virescens & $53.8,117$ & $18-49$ (L) \\
B. lima & 0,1 & 43 (L) \\
Mytilus edulis galloprovincialis & 0,1 & 22 (APA) \\
Septifer virgatus & 0,13 & $19-39$ (APA) \\
S. bilocularis & 0,28 & $20-34$ (APA) \\
Hormomia mutabilis & 0,42 & $10-24$ (APA) \\
\hline
\end{tabular}

* collected on two occasions.

\section{Distribution}

The hydroids of the transitional form have been found only in the intertidal zone of Kôshima Island, Miyazaki Prefecture, Kyushu, southern Japan. The present form has never been found in many other surveyed localities in Kyushu, Shikoku, Honshu, Hokkaido, and their neighbouring islands (Kubota, 1992b), nor in the Nansei Islands (Kubota, unpubl. data). The new form may have a very restricted distribution.

\section{Acknowledgements}

I wish to express my sincere gratitude to Dr. Robert Hughes and Dr. Mark Grygier for their kind assistance in improving the manuscript. Many thanks are due to Dr. Kunio Watanabe, Mr. Fujio Kanchi, and Mr. Naotsugu Yamaguchi (Kôshima Field Station, Primate Research Institute, Kyoto University), and Mr. Taiji Yamamoto and Mr. Fujio Nozaki (Seto Marine Biological Laboratory, Kyoto University), for their help in collecting the material. Thanks are also due to Miss Aki Nakayama for her kind assistance in rearing the host. The study was supported by a Grant-in-Aid for Scientific Research (No. 06839015) from the Ministry of Education, Science, Sports and Culture, Japan.

\section{References}

Kubota, S. 1978. The polyp and medusa of a commensal eutimid hydroid associated with a mussel from Oshoro, Hokkaido. Annot. zool. Japon., 51(3): 125-145.

Kubota, S. 1979. Occurrence of Eutima cirrhifera (Kakinuma) at Akkeshi, Hokkaido, associated with a cockle, Clinocardium californiense. Annot. zool. Japon., 52(4): 225-234.

Kubota, S. 1983. Studies on life history and systematics of the Japanese commensal hydroids living in bivalves, with some reference to their evolution. J. Fac. Sci. Hokkaido Univ., Ser. 
6, Zool., 23(3): 296-402, pl. X.

Kubota, S. 1984. A new bivalve-inhabiting hydroid from central Japan, with reference to the evolution of the bivalve-inhabiting hydroids. J. Fac. Sci. Hokkaido Univ., Ser. 6, Zool., 23(4): $454-467$.

Kubota, S. 1985a. Systematic study on a bivalve-inhabiting hydroid Eucheilota intermedia Kubota from central Japan. J. Fac. Sci. Hokkaido Univ., Ser. 6, Zool., 24(2): 122-143.

Kubota, S. 1985b. Morphological variation of medusa of the northern form of Eutima japonica Uchida. J. Fac. Sci. Hokkaido Univ. Ser. 6, Zool., 24(2): 144-153.

Kubota, S. 1990. A new host of the southern form of Eutima japonica Uchida (Hydrozoa, Leptomedusae) in Japan. J. Fac. Sci. Hokkaido Univ. Ser. 6, Zool., 25(2-4): 104-105.

Kubota, S. 1992a. Eucheilota intermedia Kubota is a distinct taxon and the third form of Eutima japonica Uchida (Hydrozoa; Leptomedusae). Zool. Sci., 9: 231-235.

Kubota, S. 1992b. Four bivalve-inhabiting hydrozoans in Japan differing in range and host preference. Sci. Mar., 56(2-3): 149-159.

Kubota, S. 1993. The second example of metamorphosis of the medusa from the intermedia form to the southern form in Eutima japonica (Leptomedusae, Eirenidae). Publ. Seto Mar. Biol. Lab., 36(1/2): 95-97.

Uchida, T. 1925. Some hydromedusae from northern Japan. Jap. J. Zool., 1: 77-100. 